\title{
富士地区における溶岩層の水文地質的特徵
}

\author{
村下 敏夫*
}

\section{Hydrogeologic Features of Lava-Flows in Fuji Region}

Toshio Murashita*

Many aquifers are hydrogeologically classified as two types of soil and rock.

The pore and permeability of fractured rocks are larger than those of soil. In permeable zones of fractured rock, ground water is very easy to flow, and water level rises rapidly under rainfall.

The lava-flows in Fuji region with cooling joints, fractures, tubes, vesicles have the highest transmissivity. According to the observation data of wells in the lava-flows, the cyclic fluctuations of the water level reflect recharge from seasonal rainfall. The serious salt-water intrusion into the lava-flows since 1960 occurred as the result of overdraft in the region.

The management of ground-water resources was started in 1967, and the net effect of the regulation of pumping is the rapid rising of the regional water level and the recovery of fresh water in the salt-water contaminated lava-flows after several years.

I まえがき

帯水層には、水文地質的に大別して二つの型があ る。一つは有効間隙を有する土、例えば砂・磁から 成る地層、他の一つは割れ目・空洞などが連続して 存在する岩石、例えば溶岩層などである。

君島(1934)は、土砂の間隙に貯留しまたは移動す る「地下水」に対して、地中の割れ目、腺・空洞 その他岩盤内の溝を流れる水を「地下川」として区

*地質調查所 Geological Survey of Japan
別した。そして、地下川の流速は地下水の流速に比 べて非常に大きく、また、地下川の水位の変動は降 雨に従う、と地下川の特徴を例をあげて説明してい る。

筆者は、1960年に富士市の田子ノ浦港周辺の深井戸 に塩水(村下、1982)が侵入し、水質の悪化のために 被圧地下水の利用価値が著しく低下する兆しがあっ たので、翌年から地質調查所の経常研究費をもって 我が国の海岸地帯における地下水の塩水化に関する 研究を始め、1981年春まで継続した。富土市におけ る研究の一部は、機会あるごとに発表(村下・岸、 
1967 ; 村下、1974、1977、1982)し、塩化物イオン の増加に、一つは大きな季節変動を繰り返して急增 する型と、一つはほとんど季節変動を示さないで渐 増する型とがあり、前者は溶岩層、後者は火山砂磷 層での現象であることを指摘した。

我が国の山地には、溶岩層類似の帯水層があるの で、君島のいう「地下川」に関する参考資料として、 富士地区における溶岩層の水文地質的特徵を、地下 水位・塩化物イオンの変動を通して、改めて紹介す る。

\section{II 地下地翼}

富士地区において、地下水利用と関係が深い地層
は、弾性波探査の結果や水井戸の資料などに基づい て区分すると、6 層ある。各層の特徵は、概略次の とおりである。

A㾍本層は砂啋と粘土を主体とする。本層は、 富士川扇状地、潤井川左岸低地、浮島原(和田川以 東の低湿地)に分布する沖積層である。

B扈本層は富士火山溶岩層である。低地におけ る本層の分布範囲は図-1に示すとおり、西は富士市 街地の西はずれ、柚木一水戸島一三四軒屋を結ぶ楾 から、東は今泉小学校を通って和田川に沿う南北の 線までの間である。本層が厚いのは分布域の中央部 で、厚さ20〜 40m、火山灰層または火山砂喽層を挾 んで 2 層位に分かれ、上部は堅硬、下部は多孔質で 割れ目に富む $\left(k \div 1 \times 10^{-1} \sim 1 \times 10^{-2} \mathrm{~cm} / \mathrm{s}\right)$ 。分布域

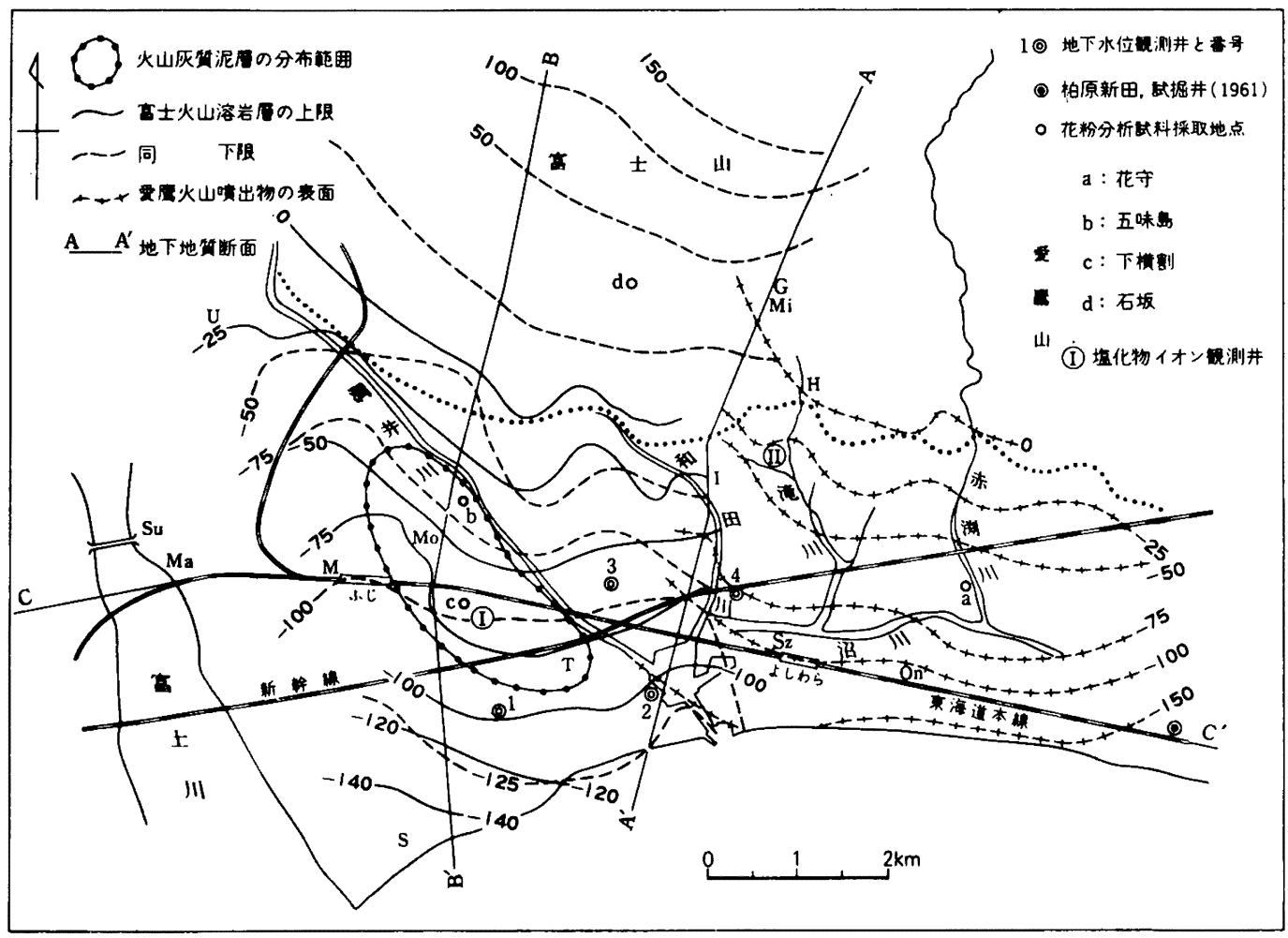

$\mathrm{On}$ : 大野新田, $\mathrm{U}$ : 柚木, $\mathrm{M}:$ 水戸岛, $\mathrm{S}$ : 三四軒屋, $\mathrm{I}:$ 今泉, $\mathrm{Mi}:$ 三ッ沢, $\mathrm{Su}:$ 水神, $\mathrm{G}:$ 神戸, $\mathrm{Mo}$ : 本市場, $\mathrm{T}$ : 数, $\mathrm{H}$ : 原田, $\mathrm{Ma}$ : 松岡, $\mathrm{Sz}$ : 鈴川

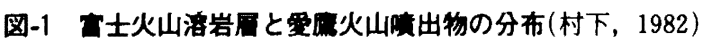

Fig. 1 Distribution of Fuji Lava-Flows and Ashitaka Volcaniclastic Material 
の東部、西部および海岸に向かって厚さが薄くなり、 東部では多孔質、西部では堅硬な岩質に変わる。

富士山麓の本層は幾層にも分かれ、層間に火山 灰・火山砂碟を挾むことが多い。層厚はまちまちで、 西部の穴原・大久保で15４0m、中央部の大㴊～石 坂で $40 \sim 60 \mathrm{~m}$ 、東部の神戸で25〜 40m、最大は三ツ 沢の約 $150 \mathrm{~m}$ である。

なお、富士川沿いに分布する溶岩層は不透水性で ある。

C屏本層は火山灰質泥層を主体とし、図-1に示 すとおり低地の一部に分布する。厚さは最大 $30 \mathrm{~m}$ にも及ぶ。

D届 本層は、富士火山体では火山砂碏・火山灰 など(古富士泥流)から成り、転石を混える $(k \fallingdotseq 1 \times$ $\left.10^{-3} \sim 7 \times 10^{-3} \mathrm{~cm} / \mathrm{s}\right)$ 。低地では疑灰角喽岩層で、

地下水位観測 2 号井の掘さく試料についての沢村孝 之助博士の鑑定によれば、約 $110 \mathrm{~m}$ 以深が本層であ る。その分布は B 層の分布範用とほぼ同じである が、低地での本層が古富士泥流であるか、さらに古 い富士火山噴出物であるかは、上記の試料鑑定だけ では判断しにくい、という。

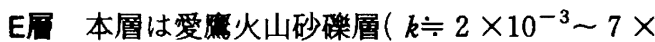

$10^{-3} \mathrm{~cm} / \mathrm{s}$ )である。本層は和田川〜赤渆川間の浮島 原北部では、層厚 1 ～2m の紫葆辉石安山岩質火山 灰(沢村博士鑑定)によって上部層と下部層に分かれ る。上部層は堅く、下部層は軟かい。

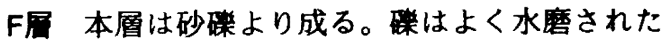
円磍で未固結である。本層は富士川寄りで浅く分布 し、松岡では A 層下位、海岸近くでは B 層または D 層下位にある。

本地区における東西方向の地下地質断面は、図-2 に示してある。6 層のうち、本文で説明の対象とす る地層は、B 層(溶岩層)と $\mathrm{D}$ 層( 灰角磁岩層) ・ $\mathrm{E}$ 層(火山砂磁層)である。

\section{III地下水位と变動}

\section{1. 地下水位}

富士山麓における溶岩層の地下水位は、海抜高度 がおおよそ $150 \mathrm{~m}$ を超えると、同層の最下部近くに あるか、全く空の状態となって下位の古富士泥流に あるところもある。しかし、150m 以下に下がると、 水位が浅く一一带水深が大きく一一なり、低地に移 行するところで、地下水の一部は泉となる。低地で

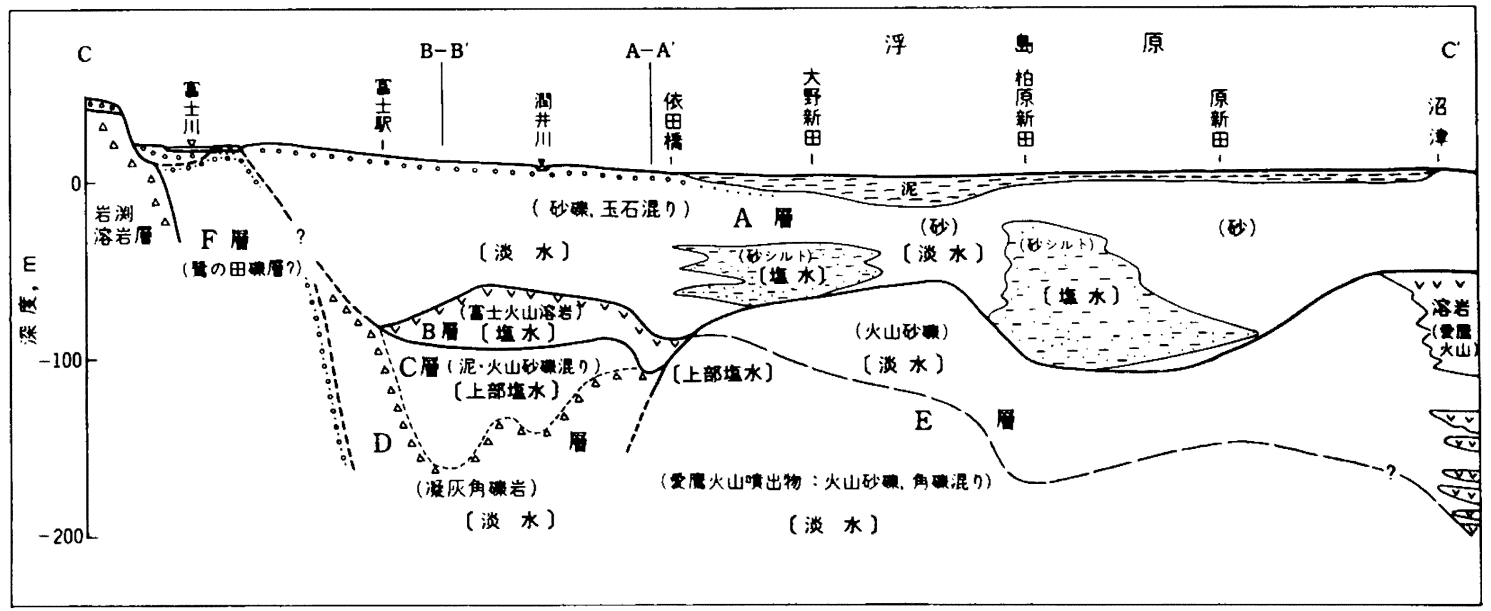

図-2 水文地精断面図(浮島原以外の塩水は侵入塩水)(村下, 1982)

Fig. 2 Hydrogeological cross section. 
は、非揚水のときに大部分の井戸が自噴状態になる。

地下水位観測記録(静岡県、1984)によると、1983 年の水位は、溶岩層に達する 1 号井(深度 $106 \mathrm{~m}$, 位 置は図-1参照)で、月平均海抜標高 $4.17 \mathrm{~m}$ (最低 7 月 $3.33 \mathrm{~m}$ 、最高 8 月 $4.76 \mathrm{~m}$ ) であった。また、同じ 3 号井 (深度 $100 \mathrm{~m}$ ) は、月平均海抜標高 $4.76 \mathrm{~m}$ であっ た。

凝灰角碟岩層に達する 2 号井(深度 $180 \mathrm{~m}$ )の水位 は、1983年の月平均海拔標高 $4.98 \mathrm{~m}$ (最低 7 月 3. $56 \mathrm{~m}$ 、最高11月 $5.86 \mathrm{~m}$ )であった。

火山砂磞層の同年の水位は、 5 号井(図-1で、滝 川の右岸にある(11)の東方約 $1 \mathrm{~km}$ の位置、深度 $200 \mathrm{~m}$ ) で、海抜標高 $6.43 \mathrm{~m}$ を年間保って変動しなかった。 以上のとおり、当地区の地下水位は、下位層の方 が高い。

\section{2. 地下水位の変動}

1966年〜1975年の10年間にわたる地下水位記録 （図-3）は、溶岩層と凝灰角喽岩層とで異なった変動 を示している。

富士山体における降水量は、測候記録が少ないの で以前から推定の域を出ないが、海抜 $500 \mathrm{~m}$ 以下の 地帯では1, 900 2,000mm である。高度が高くなる と、降水量がこれよりも多いといわれている。冬期 間は積雪が多く表土が涷結するので、この期間の地 下水補給は高度が低い地帯に限られることも考えら れる。

富士市で測候記録が最も豊富なのは、静岡県茶業 試験場富上分場(海抜高度 $80 \mathrm{~m}$ )であろう。ここにお ける1948年 7 月〜1973年 7 月の 25 年間の月平均降水 量は、最小が 1 月の $79.1 \mathrm{~mm} 、$ 最大が 6 月の
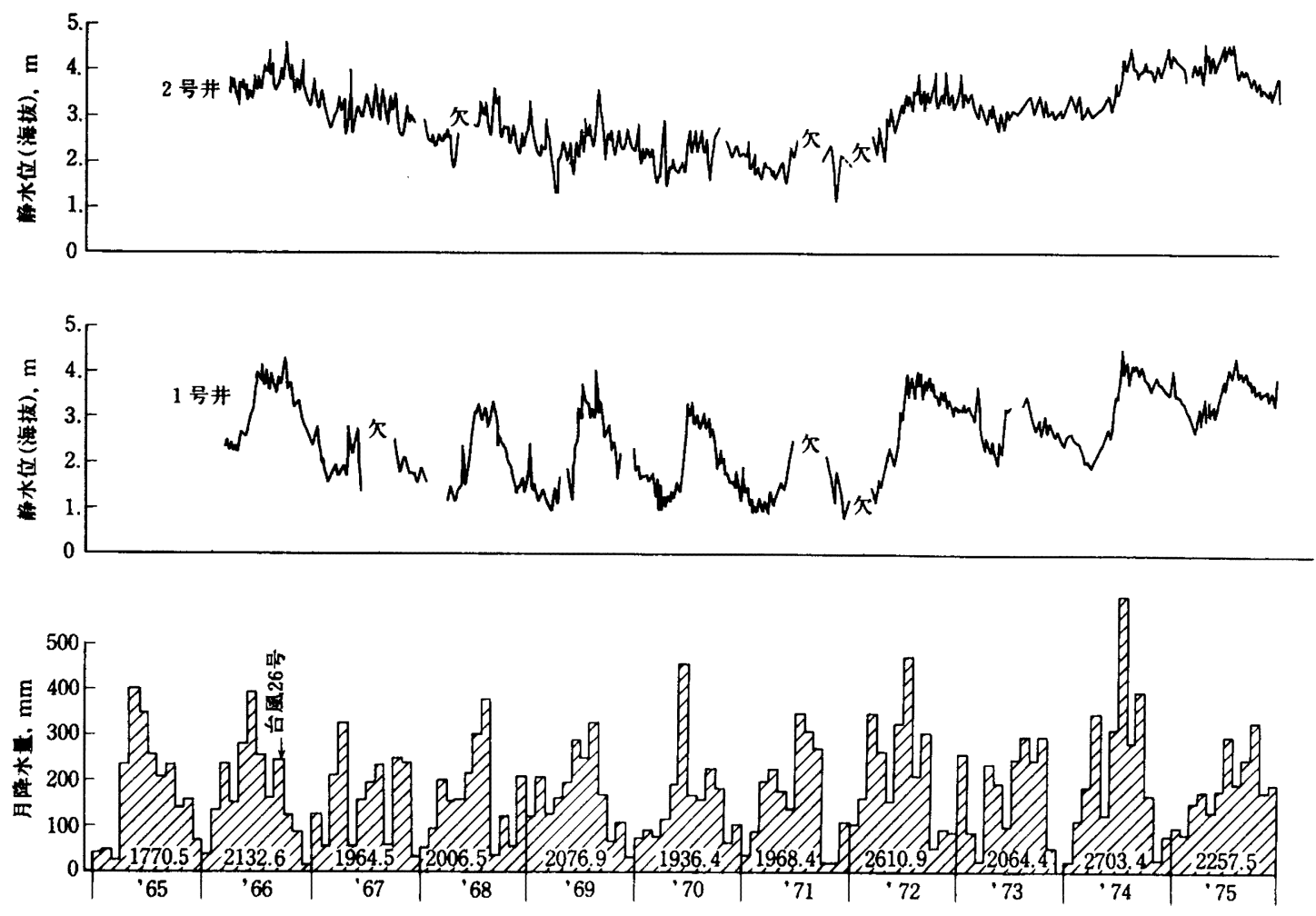

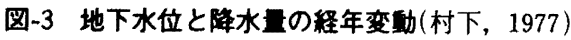
1 号井は溶岩㕌，2号井は疑灰角䂣岩層加採水する井戸

Fig. 3 Variations of annual ground-water level and rainfall 1-lava-flow aquifer; 2 -tuff breccia aquifer. 


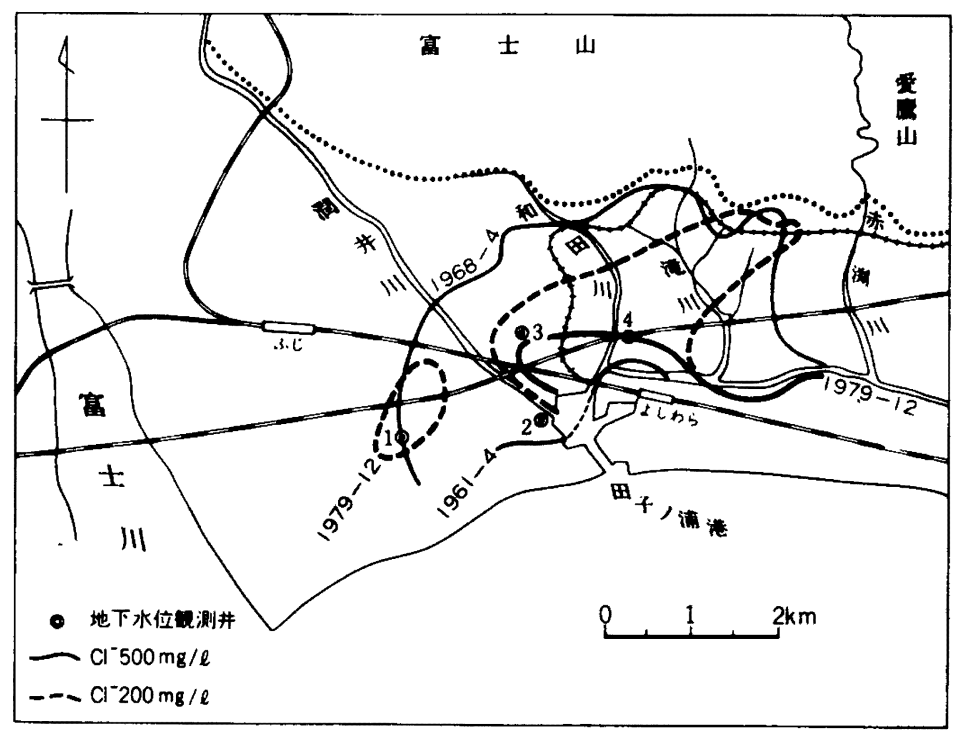

図-4 醏水化城の消長(村下, 1982)

Fig. 4 Enlargement and reduction of salt-water encroachment area due to withdrawal of artesian water.

293. $4 \mathrm{~mm}$ である。降水量が100mm 以下の月は12月 $\sim 2$ 月の 3 か月、 $200 \mathrm{~mm}$ 以上の月は 4 月〜 9 月の 6 か月である。この 6 か月間が年降水量の $66.5 \%$ を 占めている。なお各図の降水量は、上記分場の測候 記録に基づいている。

図-3のとおり、地下水位の変動は溶岩層で著しい。 1 号井の水位は、 5 月になると急上昇を始め、大体 6 ～ 8 月に最高となり、9月に入ると下降を始めて、 12月から翌年 4 月までの間に最低となる。水位の年 較差は $1.5 \sim 2.0 \mathrm{~m}$ 、降水の影響は 1 か月後によく水 位に現れる(村下、1977)。

凝灰角䃯岩層の 2 号井の水位は、自然状態では季 節変動が小さいが、周辺の揚水井戸の影響を強く受 けている。したがって、同図では年末一年始、5月 上旬、8月中旬(盆休み)の揚水停止期間に水位が急 上昇している。そして、2 号井は時々自噴状態になっ て、水が観測井の管頭から溢流して観測が不可能に なることがあり、梅雨後半の集中豪雨や台風時の降 雨直後にも、同様の現象が見られた。
火山砂磞層の地下水位は、前記 5 号井の記録の之 おり、降水の影響をほとんよ゙受けない(村下、1977、 1982)。

\section{N 塩水侵入}

富士地区で1960年 7 月に最初に発見された $\mathrm{Cl}^{-}$ $500 \mathrm{mg} / \ell$ の深井戸は、国鉄吉原駅のすぐ北にある 深度約 $100 \mathrm{~m}$ の溶岩層に達する井戸であった。この 井戸の $\mathrm{Cl}^{-}$は、同年末には $1,000 \mathrm{mg} / \ell$ 、翌年 1 月 には3,300mg/ $\ell$ となり、廃井になった。

1961年春、田子ノ浦港周辺の深井戸一一非揚水時 には自噴一い、塩水となったが、夏期にはごく一 部を除いて淡水に戻った。しかし、同年秋には再び 塩水となり、かつ塩水化する井戸が内陸に広がった。 塩水化の範囲は、夏期に縮小、冬期に拡大の季節 変動を繰り返して1962年春には前年よりも600〜 $700 \mathrm{~m}$ 内陸へ、翌年春には更に400～500m 内陸へと 年を追って拡大した。そして、1968年の塩水化が最 
も顥著で、吉原市街地の大半が侵された(図-4)。

一方、1965年春から溶岩層が分布しない和田川以 東の浮島原で塩水化が発生し、滝川沿岸の塩水化は、 おおよそ $100 \mathrm{~m}$ 以浅の火山砂喽層上部層で始まっ た。しかし、塩化物イオンは、溶岩層の場合とは著 しく異なり、季節変動をほとんど示さないで増加し ている。

図-5は、溶岩層と火山砂磁層とでは塩化物イオン の変動が異なる事例である(位置は図-1参照)。なお、 溶岩層の塩化物イオンに降水の影響が明瞭に現れる のは、1 か月半から 2 か月後である(村下、1982)。

富士地区における地下水の塩水化は、1968年を境 に拡大を停止し、以後は縮小の方向に向かった。淡 水化は、溶岩層分布域では影著で(図-6)、1973年春 の塩水化域は1968年の約 $2 / 3$ に縮小し、同年末には和 田川の河口周辺の限られた範囲になった。浮島原の 塩水化域は、海岸寄りに徐々に縮小しているが、現 在最大範囲の $2 / 3$ 程度に止まっている(図-4)。

富士・愛鵘両火山山麓で淡水化が進行しているの は、地下水塩水化防止対策として工業用水道の整備、 製紙工場などにおいて水使用の合理化を積極的に行 い、地下水汲み上げ量を削減したからである(村下、 1977、1982)。詳細な説明は省くが、上記の地下水 対策が実行できたのは、地下水位と塩化物イオンの 定期観測結果——地下水の汲み上で量が年間一定
で、塩水化が夏(豊水)期に鈍化し、冬(晹水)期に進 行する——を考察して、地下水補給量に見合った汲 み上げ量に制限すれば塩水化防止が可能であると判 断されたからであった。そして、汲み上げ量は、全 域の地下水位が内陸(補給)側で高く、海岸(排出)側

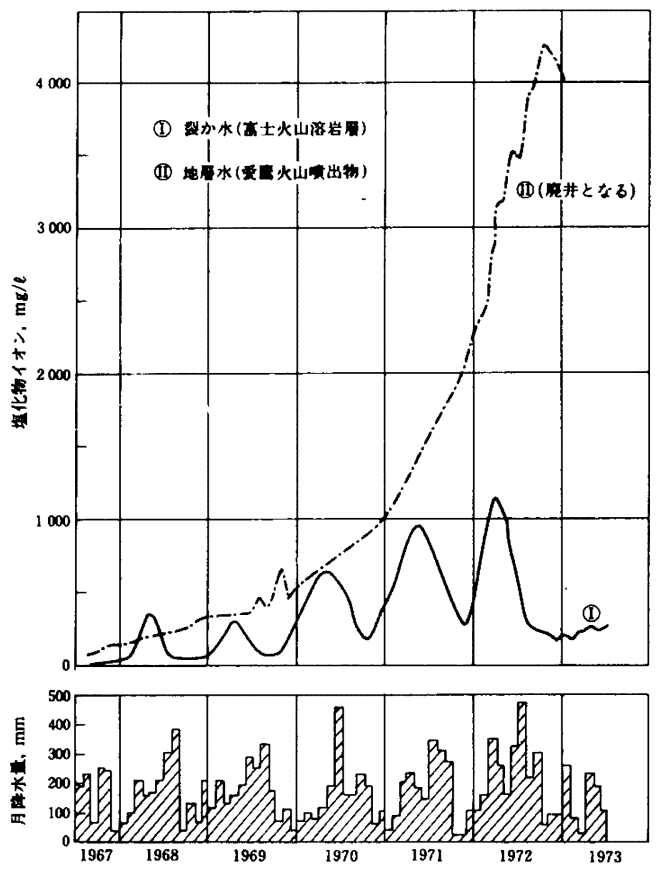

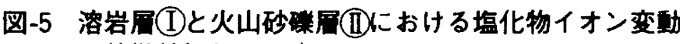
の特徴(村下, 1974)

Fig. 5 Variation of chloride concentration with time of pumping wells in different aquifer.

(I)-lava-flow aquifer; (II)-volcanic sand aquifer.

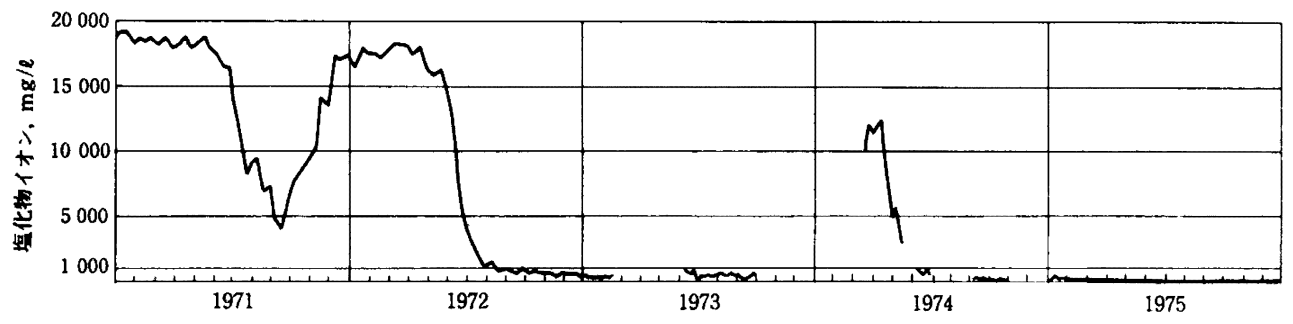

図-6 地下水汲み上げ圈削娍措四に伴う奻果

(海岸から1.2km 内陸にある浴岩層からの採水井の塩化物イオン変動)(村下，1977)

Fig. 6 Effect of ground-water management on prevention of salt-water intrusion. Great variation of chloride concentration of well in lava-flows on $1.2 \mathrm{~km}$ inland from coast. 
で低く一塩水化発生以前の地下水位状態——なる ように削減された。

\section{$\mathrm{V}$ 考察}

富士地区における被圧地下水の塩水化に関する研 究を通じて、塩水化の消辰に二つの型があることが、 明らかになった。一つは、溶岩層の塩水化で、降水 量の増减に応じて $\mathrm{Cl}^{-}$の季節変動が大きい。他の 一つは火山砂磷層の塩水化で、降水量にほとんど影 響なく $\mathrm{Cl}^{-}$の季節変動もほとんど示さない。 後者の型は、我が国の海岸地帯で発生している一 般的な塩水化で、前者の型はこの地区特有のもので ある(村下、1982)。このような現象は、帯水層が割 れ目・空洞等に富む岩石と土の粒子間隙から成る地 層との水文地質的性質の相違に起因する。

溶岩は、本質的には堅硬かつち密で、不透水性の 岩石であるが、富士地区の場合には流動・冷却・固 結の過程で生じた不規則な割れ目や小さな空洞が多 い。溶岩層の透水係数 $\left(1 \times 10^{-1} \sim 1 \times 10^{-2} \mathrm{~cm} / \mathrm{s}\right)$ は、 通常の砂・磷と同程度の值であるが、実際の間隙は 土とは違って透水には極めて有効な通路であり、パ イプに類似した「透き間」であろう。

水は、溶岩層の透き間を自由に通過できるので、 地下水位が海面よりも下がると、海水が陸側へ侵入
し、水位が逆に高くなると淡水が海側へ流出する。 そして、溶岩層(一般に岩石)の貯留(包藏)性は、火 山砂磷層(一般に土)に比べて小さいと考えられる。

\section{VI あとがき}

割れ目・空洞などが連続して存在する岩石を流れ る水は、天水の影響をうけて水量(水位)の增減が短 期間に起こり、君島の「地下川」の性質をもってい る。

この性質は、水資源開発、地下水の污染、土木工 事等の場合、水量の確保、問題の発生・対策なよ゙の 決定に際してきわめて重要な要素となろう。

\section{参考文触}

君島八郎(1934)：「地下水」, 丸善, 434p.

村下敏夫・岸 和男(1967)：地下水の塩水化について，第 1 報 塔岩帯水層の水理地兵学的性質. 地調月報, 18, $379 \sim 392$.

村下敏夫(1974)：静岡県における地下水の塩水化. 工業用 水, $190,26 \sim 37$.

村下敏夫 (1977) : 静岡県富士市における地下水の塩水化. 工業用水, $225,30 \sim 42$.

村下敏夫(1982)：本邦における地下水の塩水化. 地調月報, 33, $479 \sim 530$.

静岡県 (1984)：地下水調查報告書(58年 1 月～12月), 262p.

（受付：1984年 7 月30日，受理：1984年10月31日） 